\title{
WTropical Wetland Journal
}

Journal homepage: twj.ulm.ac.id | Published by Postgraduate Program - Lambung Mangkurat University | e-ISSN: 2654-279X

Original article

DOI 10.20527/twj.v6i1.84

\section{Effects of Some Ameliorant on Chlorophyll a, Chlorophyll b and Total Chlorophyll on Sweet Corn Growth with Raised-Bed Soil Materials}

\author{
Ronny Mulyawan ${ }^{1}$, Akhmad Rizali Saidy², Rahmi Zulhidiani ${ }^{3}$ \\ 1 Departement of Agroecotechnology, Faculty of Agriculture, Lambung Mangkurat University, Banjarbaru 70714, \\ Indonesia. \\ 2 Departement of Soil Science, Faculty of Agriculture, Lambung Mangkurat University, Banjarbaru 70714, \\ Indonesia. \\ 3 Departement of Agronomy, Faculty of Agriculture, Lambung Mangkurat University, Banjarbaru 70714, \\ Indonesia. \\ * Correspondence: ronny.mulyawan@ulm.ac.id; Tel. +62-896-9188-7652
}

Received: 26 June 2020; Accepted: 20 July 2020; Published: 30 July 2020

\begin{abstract}
The raised-bed soil is a land management technology in South Kalimantan. Adding ameliorant to the raised-bed soil as an effort to increase the utilization of support for the cultivation land. Chlorophyll or leaf green substances found in all green plants that carry out photosynthesis. Ameliorant applications can increase the chlorophyll of plants to optimize plant growth. This study aims to look at the effect of giving several types of ameliorant to of chlorophyll (chlorophyll-a, chlorophyll-b and total chlorophyll) and the growth of corn planted on raised-bed soil. This research is an experiment in the laboratory and a greenhouse. This research was conducted using a Completely Randomized Design (CRD) Single Factor with the treatment tested was the type of ameliorant soil without treatment (control - K), soil + agricultural lime (dolomite - C), soil + palm empty fruit bunch ash (S), soil + rice husk ash (P) and soil + coal ash (B). All treatments were repeated 5 (five) replications so that there would be 25 units of the experiment. The results showed that the application of ameliorant in raised-bed soil using dolomite and oil palm empty fruit bunches ash with a dose of 5 tons ha-1 affected of chlorophyll-a and total chlorophyll in the growth of corn planted in raised-bed soil materials.
\end{abstract}

Keyword: coal ash, dolomite, lime, raised-bed soil, rice husk.

\section{Introduction}

The most extensive tidal land in South Borneo is in Barito Kuala Regency with 398,892 hectares, which has a large enough potential to be developed into an agricultural or plantation area. Tidal land, including potential land, if managed well, productivity is not inferior compared to another land. Land and environmental conditions on tidal land can be overcome by using technology based on local wisdom. One of the local pearls of wisdom of the people of South Borneo that is used in agricultural cultivation on tidal land is the making of raised-bed soil. The raised-bed soil is dug up 
and then piled up to raise a portion of the land (Nazemi et al., 2012). Problems with the chemical nature of soils cause low raised-bed soil productivity, one of which is low soil $\mathrm{pH}$. Research conducted by Rasmadi (2003) shows that the range of soil pH support ages varying on average between 3.0-4.0 which can be explained sourly.

Application of ameliorant is an effort to improve soil fertility, increase soil $\mathrm{pH}$, and indirectly affect plant physiology, which in turn will affect plant production. An increase in carbohydrates can indirectly be seen from the size of the chlorophyll in plant leaves. The application of ameliorant in the form of coal ash in the soil can increase the availability of nutrients such as Natrium (Na), Potassium (K), Calcium (Ca), Magnesium (Mg), and Boron (B), and can increase the concentration of pigments for photosynthesis (chlorophyll) in plants (Thetwar, 2001; Basu et al. , 2009).

Chlorophyll or leaf green substances found in all green plants that carry out photosynthesis. Photosynthesis is the process of changing inorganic compounds $\left(\mathrm{CO}^{2}\right.$ and $\left.\mathrm{H}_{2} \mathrm{O}\right)$ into organic compounds (carbohydrates) and $\mathrm{O}^{2}$ with the help of sunlight. Chlorophyll in plants has three functions in the process of photosynthesis namely use solar energy, triggering $\mathrm{CO}^{2}$ fixation to produce carbohydrates and providing energy for the ecosystem as a whole. Carbohydrates produced in photosynthesis are converted into proteins, fatty nucleic acids and other organic molecules (Ai \& Banyo, 2011). The amount of chlorophyll in leaves varies in each species of plant. This depends on environmental and genetic factors. Based on these descriptions, it can be hypothesized that the application of different ameliorant materials will result in changes in soil chemical properties, chlorophyll in leaves, and different plant growth. This study aims to look at the effect of giving several types of ameliorant to of chlorophyll (chlorophyll-a, chlorophyll-b, and total chlorophyll) and the growth of corn planted on raised-bed soil.

\section{Materials and Methods}

\section{Material}

This research was held in the Greenhouse and Soil Chemistry and Physics Laboratory of the Faculty of Agriculture, Lambung Mangkurat University, Banjarbaru. Soil sampling in the field is done using a hoe at a depth of $0-30 \mathrm{~cm}$ at several points of soil sampling. After cleaning from the remains of plants, soil samples are mixed evenly and then air-dried. After drying, the soil samples are crushed and filtered with a sieve of $\leq 2 \mathrm{~mm}$. Soil sampling was taken in Trantang, Mandastana, Barito Kuala, South Borneo.

Methods

Air-dried soil samples were weighed as much as five $\mathrm{kg}$ and put into a trial pot. Then, the ameliorant material according to the treatment (Control (K), Coal fly ash (B), Dolomite $\left(\mathrm{CaMg}\left(\mathrm{CO}_{3}\right)_{2}\right)(\mathrm{C})$, Rice husk ash (P) and Oil palm empty fruit bunch ash (P)) was added to the experimental pot with a dose 12.5 g.pot $^{-1}$ equivalent to five tons ha-1 and incubated at $70 \%$ water content field capacity for 1 (one) month. During the incubation period, the pot solid water content of the experiment was maintained at the level of $70 \%$ field capacity. All treatments were repeated five replications, so that, there were 25 experimental units. Then, the corn seeds are planted in each pot as much as 3 (three) seeds. Replanting is done after the corn plant is 2 (two) weeks old. The observations made were looking at the chlorophyll-a, chlorophyll-b and total chlorophyll of corn plants using atomic adsorption spectrometer. Analysis of chlorophyll of corn plants was made after minimum of three pots of corn plants showed $50 \%$ of the first male flower. Leaf samples used for chlorophyll analysis in leaf was extracted with $80 \%$ acetone (method Lichtentaler \& Welburn) (Sinha et al., 2013). Analysis of variance was performed on the data of chlorophyll-a, chlorophyll-b and total chlorophyll to quantify the effect of some Ameliorant. Statistical analyses were performed using GEN-STAT 12th Edition (Payne, 2008).

\section{Results and Discussion}


The application of soil ameliorant has a significant effect on the chlorophyll of corn plants. The chlorophyll-a plant in the treatment of dolomite application is higher than the application of coal ash, without treatment (control) and rice husk ash, but not significantly different from the application of oil palm empty fruit bunches (Figure 1). This is because chlorophyll directly plays a role in the conversion of radiation energy into chemical energy and absorbs and transports energy to the molecular reaction center. Meanwhile, chlorophyll b serves as an absorbent of radiation energy, then forwarded to chlorophyll a. Chlorophyll makes up 75\% of the total chlorophyll. The chlorophyll in plants is about one percent of the dry weight of plants (Sumenda et al., 2011; Handayani et al., 2011).

The results of the analysis of variance also showed that the application of ameliorant had significant effect on the chlorophyll-a of corn plants (Figure 1). Chlorophyll is a pigment giving color to the green plant. This pigment plays a role in the process of photosynthesis of plants with absorb and convert light energy into chemical energy. Chlorophyll-a is greater than the chlorophyll $b$ in pigment. Chlorophyll-a role in the first phase of photosynthesis. Ameliorant applications with higher $\mathrm{Ca}$ and $\mathrm{Mg}$ affect the chlorophyll a as in the application of dolomite and oil palm empty fruit bunches (Ai \& Banyo, 2011).

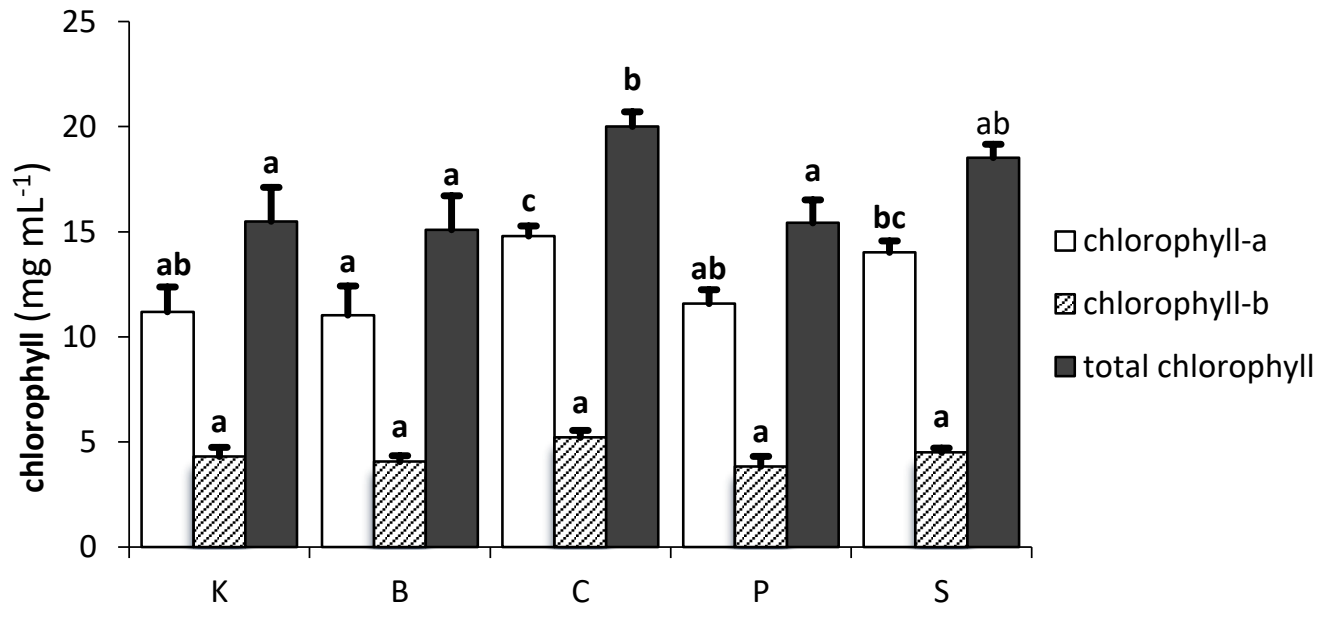

Description

$\mathrm{K}$ : Control (without the addition of ameliorant)

B : Coal fly ash a dose 12.5 g.pot $^{-1}$ equivalent to 5 tons ha-1

$\mathrm{C}$ : Dolomite $\left(\mathrm{CaMg}\left(\mathrm{CO}_{3}\right)_{2}\right)$ a dose 12.5 g.pot $^{-1}$ equivalent to 5 tons ha-1

$\mathrm{P}$ : Rice husk ash a dose 12.5 g.pot $^{-1}$ equivalent to 5 tons ha- ${ }^{-1}$

$\mathrm{S}$ : Oil palm empty fruit bunch ash a dose 12.5 g.pot $^{-1}$ equivalent to 5 tons ha-1

The line above the bar is the standard deviation (standard error) of the average value $(n=5)$. The same letter above the bar indicates that the treatment has a no different effect based on the results of Duncan's Multiple Range Test (DMRT) at a level of $\alpha 5 \%$.

Figure 1. The average value of chlorophyll-a, chlorophyll-b and total chlorophyll sweet corn plant in raised-bed soil with ameliorant application.

Application of ameliorant had no significant effect on the chlorophyll b of corn plants (Figure 1). The average chlorophyll-b of corn plants with the application of several ameliorant ranged from 4.06 to $5.21 \mathrm{~g} \mathrm{~mL}^{-1}$. Thing. The chlorophyll a is always higher than chlorophyll-b (Afandi et al., 2013). Chlorophyl- b is only found in the pigment of the light-catching antenna system, while chlorophyll-a is in the photo-system reaction center and also in the antenna pigment (Sumenda et al., 2011; Handayani et al., 2011).

The total chlorophyll of corn is significantly influenced by soil ameliorant application. The average total chlorophyll of corn in all treatments ranged from 15.1-20.0 g.mL $\mathrm{m}^{-1}$. The total chlorophyll of plants in dolomite applications is higher than the total chlorophyll in the application of coal ash, rice husk ash, and control (Figure 1). The Figure 1 shows that the application of oil palm 
empty fruit bunch ash on the raised-bed soil produces total chlorophyll that is not different from dolomite, coal ash, rice husk ash, and control. This is because these treatments can supply elements for the formation of chlorophyll in plants and suppressing elements that can be inhibitors in plant metabolism. The effect of $\mathrm{Al}$ in the soil can cause a decrease in the rate of photosynthesis and chlorophyll in rice plants (Shi, 2004). Increasing $\mathrm{Al}$ in roots and leaves causes $\mathrm{Mg}$ concentrations in both organs to decrease, so that the chlorophyll of plants and photosynthetic active radiation (PAR) decreases (Chen et al. 2005).

\section{Conclusion}

Results obtained in this study revealed that application of ameliorant in raised-bed soil using dolomite and ash of empty oil palm bunches with a dose of five tons ha-1 effect of chlorophyll-a, and total chlorophyll due to the addition of nutrients that support photosynthesis for the growth of corn on raised-bed soil material.

\section{References}

Ai, N.S., Banyo, Y. (2011). Konsentrasi klorofil daun sebagai indikator kekurangan air pada tanaman. Jurnal Ilmiah. 11(2): 167-168.

Basu, M., Pande, M., Bhadoria, P.B.S., Mahapatra, SC. (2009). Potential flyash utilization in agriculture: a global review. Progress Natural Science. $19: 1173-1186$.

Chen, L.S., Qi, Y.P., Smith, B.R., Liu, X.H. (2005). Alumunium induced decrease in $\mathrm{CO}_{2}$ assimilation in citrus seedlings is unaccompanied by decreased activities of key enzymes involved in $\mathrm{CO}_{2}$ assimilation. Tree Physiology. $25: 317-324$.

Handayani, T., Basunanda, P., Murti, H.R., Sofiari, E. (2013). Pengujian stabilitas membran sel dan kandungan klorofil untuk evaluasi toleransi suhu tinggi pada tanaman kentang. Jurnal Hortikultura. 23(1): 28-35.

Nazemi, D., Hairani, A., Nurita. (2012). Prospek pengembangan penataan lahan sistem surjan di lahan rawa pasang surut. Agrovigor. 5(2) :113-118.

Payne, R. (2008). A Guide to Anova and Design in Genstat, VSN Internasional. Hempstead: United Kingdom.

Rasmadi, M. (2003). Karakteristik kimia tanah pada tukungan yang berbeda umurnya yang ditanami jeruk di daerah pasang surut. Jurnal Agroscientiae. 10(1) :25-32.

Shinha, D., S. Sharman, and M.K Dwivedi. (2013). The impact of fly ash on photosynthetic activity and medicinal property of plants. Internasional Journal of Current Microbiology and Applied Sciences. 2(8) :382-388.

Shi, G.Y. (2004). Effect of alumunium on growth and some physiological function of rice seedlings. Journal Guihai. 2 :77-80.

Sumenda, L., Rampe, H.L., Mantiri, F.R. (2011). Analisis kandungan klorofil daun mangga (Manggifera indica L.) tingkat perkembangan daun yang berbeda.. Journal Bioslogos. 1(1) :2024.

Thetwar, L.K. (2007). Studies on the effects of fly ash and plant hormones and soil metabolic activities. Asian Journal Chemistry. 19 :3515 - 3518. 